\title{
The Central Asian Track of the One Belt One Road Initiative: Opportunities and Risks ${ }^{1}$
}

\author{
R. Izimov, Z. Muratalieva
}

Ruslan Izimov - Head, Eurasian Studies Programme of the Institute of World Economy and Politics under the Foundation of the First President of the Republic of Kazakhstan; Bokeyhan Str. 10, Astana, 010000, The Republic of Kazakhstan; E-mail: iziruslan@mail.ru

Zamira Muratalieva - PhD, Associate Professor, Scientific Secretary, Institute for Strategic Analysis and Forecast of the Kyrgyz-Russian-Slavic University; Chui Str. 42, Bishkek, 720000, The Kyrgyz Republic; E-mail: nargi84@yandex.com

\begin{abstract}
With the exception of Turkmenistan, Central Asian countries have consistently viewed foreign policy as a multivector activity since their independence more than 25 years ago. In the past, this strategy has shown its effectiveness and irreplaceability. Striving to maintain a delicate balance between the interests of global and regional empires, Kazakhstan and other countries in the region continue to pursue a multivector policy today. However, this task becomes more complicated year by year as competition between regional actors gathers pace. In that respect, the emergence and implementation of the Chinese One Belt One Road (OBOR) initiative, which objectively increases the dependence of countries in the region on China, plays a special role.

This article reviews the emergence and implementation of China's OBOR initiative in Central Asia. The authors set forth Beijing's foreign policy strategy with respect to the initiative in terms of its main components in Central Asia. The cooperation of Kazakhstan and China is separately considered within the framework of the concept of linking the "Nurly Jol" state programme of infrastructural development for 2015-2019 and OBOR. Given the long-term nature of this project, forecasts are provided for the interaction of the Central Asian states with PRC within the framework of the Chinese initiative.

Additional issues relating to the coexistence of several projects in the Eurasian space, in which Kazakhstan and other countries of the region participate, are also considered. In particular, the authors analyze the role and place given by Chinese authorities to Russia within the OBOR strategy. Despite the official statements of the authorities or established plans (Beijing-Moscow high-speed railway, highway, etc.), China generally assigns an insignificant place to Russia in its strategy.

Moreover, by offering road construction projects to Moscow, Beijing apparently expects to divert Russia's attention from its own plans in Central Asia. Against this background, there is a clear response from Moscow which is most evident in Russia's desire to actively promote the Greater Eurasian Partnership project.
\end{abstract}

Key words: One Belt, One Road; Chinese initiative; OBOR; Nurly Jol; Kazakhstan; Central Asian strategy; Central Asian countries; geopolitics

For citation: Izimov R., Muratalieva Z. (2018) The Central Asian Track of the One Belt One Road Initiative: Opportunities and Risks. International Organisations Research Journal, vol. 13, no 3, pp. 128142 (in English). DOI: 10.17323/1996-7845-2018-03-08.

${ }^{1}$ The editorial board received the article in November 2017. 


\section{Introduction}

With the exception of Turkmenistan, Central Asian countries have consistently viewed foreign policy as a multivector activity since their independence more than 25 years ago. In the past, this strategy has shown its effectiveness and irreplaceability. Striving to maintain a delicate balance between the interests of global and regional empires, Kazakhstan and other countries in the region continue to pursue a multivector policy today. However, this task becomes more complicated year by year as competition between regional actors gathers pace.

The emergence and accelerated implementation of integration initiatives proposed by various centres of power raises more issues and intensifies competition in the Central Asia region. In this regard, the Chinese One Belt One Road (OBOR) initiative has undoubtedly contributed to increased competition. Year by year, its implementation sheds light on additional issues in need of resolution. In this context, Kazakhstan and other Central Asian republics find it increasingly difficult to maintain a fragile balance of power.

At the moment, OBOR clearly outweighs all other integration and multilateral cooperation projects within the Eurasian space. As a consequence, a shift towards China is apparent from the current foreign economic vectors of virtually all Central Asian republics. This is primarily due to the economic attractiveness of the Chinese initiative.

Moreover, there is a clear understanding that OBOR is a colossal geopolitical project proposed by PRC authorities, where the central role is assigned to the countries of Central Asia, and Kazakhstan in particular.

Judging by the statements of the Chairman of the People's Republic of China, Xi Jinping [2017], the measures being currently implemented and the finances allocated for this project, the initiative can be confidently predicted to provide a long-lasting effect.

Finally, there is every reason to suppose that this initiative can become the core or main driver of the new foreign policy strategy of the PRC in the Eurasian space or, at least, in Central Asia.

It was all of the above that caused the active participation of the Central Asian countries in the Chinese initiative. However, the future prospects of OBOR in the Central Asian region face a number of difficulties.

In this article, the current status of China-Central Asia cooperation is analyzed through the prism of the implementation of the OBOR initiative. At the same time, special attention is paid to the problematic aspects of this interaction, taking into account the factor of competition between various centres of power within the Eurasian space.

\section{On the Origins of OBOR}

Since the early-2000s, Chinese authorities have used the format of the Shanghai Cooperation Organisation (SCO) to seamlessly resolve their issues with the countries of the Central Asian region. At the same time, in its interaction with Central Asian countries both within the SCO framework and bilaterally, Beijing almost always had to act with 
regard to Russia. But as economic relations with the Central Asian countries deepened further, Beijing could no longer confine itself solely to the SCO format, which allowed solving key issues being border-related disputes. The future prospects of the SCO were based on the task of providing an effective dialogue platform between the countries of Central Asia, Russia and China.

The appearance in 2010 of a new integration association initiated by Moscow the Customs Union of Kazakhstan, Russia and Belarus - was significant. The development of the Customs Union and the formation of the Eurasian Economic Union (EEU) as a full-fledged organization pushed China to look for more effective mechanisms to expand its influence in the West. It was at this point that the idea of forming the Silk Road Economic Belt (SREB) emerged for the first time in 2013, later forming the basis for the establishment of the OBOR format [Xi, 2014].

It was clear to Beijing that in the context of a steady increase in tension between China and the U.S., especially in the Asia-Pacific region, that it should more seriously consider land corridors as a future alternative to delivering its goods to Europe.

Taking into account the existing circumstances, the Chinese authorities decided to propose their own version of macroregional integration, dominated by China.

\section{Kazakhstan as a Key Partner in the Success Story}

In September 2013, as part of his first tour of the Central Asian countries after his election in March of the same year, Xi Jinping visited Kazakhstan. Speaking at the Nazarbayev University, the Chinese leader unexpectedly proposed an entirely new initiative to the attendees. In particular, Xi said: "With the aim of strengthening economic ties, deepening cooperation and expanding the space of development of the Eurasian countries, we can apply a new model of cooperation and jointly establish the Silk Road Economic Belt..." [Xi, 2013]. It was from that moment that a large-scale discussion of the Chinese initiative began.

From the beginning, Kazakhstan stood out as a key link in the Silk Road strategy. The initiative proposed by Chinese authorities was generally expected in Kazakhstan and in the rest of the region, since China had not submitted any specific regional foreign policy or economic strategy documents in 20 years of cooperation with the countries of Central Asia. In this regard, Beijing was to state its goals and objectives in the region in a conceptual form, and OBOR became such an initiative.

Choosing Kazakhstan was by no means accidental. According to Chinese authorities, Kazakhstan is the most stable republic in the region with both political and economic potential to become a full-fledged partner of China in its new initiative.

Singling out the advantages of Kazakhstan, the authorities of China highlighted several factors. First, Kazakhstan has strong transit capabilities because its vast territory allows implementation of various transport projects with access to Russia, the Caspian Sea and the Caucasus, Iran and the Persian Gulf, the Central Asian countries and India. Second, unlike other republics of Central Asia, Kazakhstan has remained politically stable for many years. Third, Kazakhstan offers a favourable investment climate [Lee, 2014]. 
In addition, Chinese experts believe that in the implementation of infrastructure projects, Beijing can fully rely on Kazakhstan as a country that can become an intermediary in paving the most profitable and beneficial routes through the territory of Kazakhstan, Turkmenistan, Azerbaijan and Turkey to Europe. Having the opportunity of close coordination with these countries within the framework of the Cooperation Council of Turkic-Speaking States, Astana can agree with Ankara and other countries on implementing projects in the transport sector. At the same time, it is Kazakhstan that can assist in obtaining Moscow's loyalty with respect to the implementation of OBOR projects in Central Asia. But an important condition should be the exclusion of attempts on the part of Beijing to act behind Moscow's back.

Moreover, in the opinion of Chinese authorities, Kazakhstan also has an important advantage in its wise and experienced policy-makers and the conduct of a farsighted foreign policy. Given all these factors, the Chinese authorities have chosen Kazakhstan as a key partner and link in all projects being implemented in the western orientation of OBOR.

\section{A New Impetus for Cooperation}

Kazakhstan and China had been working closely together long before the OBOR initiative was launched. It is recognized that Kazakhstan managed to reverse one of the main negative trends in interaction with China, that is, an orientation toward commodities. Cooperation between Kazakhstan and China had been limited to raw materials since 1997, with the main items of bilateral trade being the export of oil, gas and minerals. But in accordance with the new tasks set under the OBOR initiative, Kazakh-Chinese cooperation has gained a new impetus.

As a result, today their cooperation covers a great number of projects in the real sector of the economy - industrial facilities are planned and built and, importantly, waterworks are being built and modernized with the assistance of China. Currently, the largest economic development programmes in the republic are in some way associated with China. At the end of 2014, Kazakhstan developed the "Nurly Jol" State Programme for Infrastructure Development for 2015-2019 which was specifically intended to fit with the projects allocated by China within the framework of OBOR [Syroyezhkin, 2016]. Since then, a large number of projects have emerged in the real sector of economy.

One of the key programme documents regulating economic relations between Kazakhstan and China at this stage is the Kazakh-Chinese investment cooperation programme, involving the transfer of industrial facilities from the territory of China to the territory of Kazakhstan.

Initially, Kazakhstan and China agreed on projects for a total of $\$ 26.2$ billion [Zakon, 2016]. Over several years, 51 companies in the chemical industry, mining and metallurgy, engineering, infrastructure, energy, agro-industrial complex, light industry, oil refining, construction materials and information technologies will be established and modernized in Kazakhstan with the assistance of large Chinese companies. 
New enterprises will be put into operation in practically all regions of Kazakhstan: in the North Kazakhstan region, East Kazakhstan region, Almaty region and the South Kazakhstan Region. Several projects have already been implemented; for example, a plant for the production of powdered polypropylene has been modernized in the Pavlodar region.

In addition to expanding production, the construction of new transport routes is planned. Construction of new transport arteries in the vast territory of Kazakhstan as well as modernization of old ones fully meet the interests of the republic. In close cooperation with China and under the flag of the implementation of the Maritime Silk Road initiative, Kazakhstan will have an opportunity to significantly expand its transit potential.

It is a widely recognized fact that state of the art technologies have significantly reduced the distance between Pacific ports and European countries through ground corridors. Transportation time through land routes has been almost halved.

As can be seen, Kazakhstan's participation in OBOR generally provides a number of key advantages, including the development of transport and industrial potential, solution of social problems and so on. At the same time, in addition to opportunities, the implementation of OBOR also involves a number of real risks and challenges.

\section{Dynamics and Challenges from the Central Asian Perspective}

The increasing importance of Kazakhstan's relationship with China is evidenced by the frequency of meetings between regional state leaders and the Chinese leadership. Individually, Kazakhstan, Kyrgyzstan and Tajikistan are undoubtedly the closest partners with China. At the same time, in the last six months there have been marked impulses in relations between China and Uzbekistan with the first results already visible.

It is believed among experts that Kyrgyzstan and Tajikistan are more dependent on China than others, and the credit resources are allocated accordingly. Thus, according to the media, China accounts for about half of Kyrgyzstan's external debt [Khassanova, 2017].

Despite the lack of accurate data, another trend is alarming - a sharp and rapid increase in debt to China. According to the Kyrgyz media, as early as 2011 Kyrgyzstan had to pay a total of $\$ 272$ million to the PRC. By the end of 2016 this amount had increased fivefold to about $\$ 1.444$ billion [K-News, 2016].

In addition, the establishment of a Kyrgyz-Chinese development fund is under discussion, with the PRC having a 100\% share in the capital [Akchabar Print, 2017]. If it is established, Beijing will allocate \$1 billion to Kyrgyzstan [Gezitter, 2017]. The former president of the Kyrgyz Republic, A. Atambayev, during the OBOR summit held in May 2017 stated that Kyrgyzstan was ready to link the national programme "Taza Koom" with the digital Silk Road [Atambayev, 2017]. Due to the fact that this initiative is implemented on the Chinese side, China Telecom may become the potential executor of the project.

The place and role of the Kyrgyz Republic in OBOR is conditioned by the implementation of specific projects in the field of transport, as well as long-term security interests. 
The Kyrgyz track within the Silk Road Economic Belt project differs from the rest in that Kyrgyzstan, being a member of the World Trade Organization, is one of the key trade corridors of China's reach to the countries of the West. And it is the undeveloped transport corridors that largely impede the process of further deepening cooperation in the trade area. In this context, China offers the task of building the "China-Kyrgyzstan-Uzbekistan" railway within the context of the implementation of the OBOR's global strategy. The foregoing predetermines that the construction of this railway is to move into a practical stage in the coming years.

In Tajikistan, the situation is almost the same as in Kyrgyzstan with China accounting for half of the external debt [Bondarenko, 2016]. In 2016, the PRC ranked first in terms of the amount of funds invested in the economy of Tajikistan, surpassing Russia. The total scope of China's accumulated direct investment reached $\$ 1.6$ billion, or $30 \%$ of the total amount of accumulated investment, about $\$ 3.8$ billion. China's direct investments to Tajikistan totaled about $\$ 255$ million in 2016, which accounted for $71.8 \%$ of total investment for the period. In the first three months of 2017, China accounted for $58.2 \%$ of the total scope of all foreign investment, which in monetary terms is $\$ 76.6$ million [Asia-Plus, 2017].

In fact, it is clear that these two republics, like other countries, are trying to make use of the opportunities provided by China. However, in view of the size of the economies of Kyrgyzstan and Tajikistan, the loans allocated by China made up most of the gross domestic product of these republics. Against this background, one gets the impression of total dependence on the PRC.

It seems that, on the whole, the deepening of ties between Kyrgyzstan and Tajikistan with China is a natural process, especially taking into account their common border. At the same time, there are disturbing issues such as the deepening of ties with China in the military sector, as evident in Tajikistan, and the issue of land leasing.

Quite rapid changes have been observed in Chinese-Uzbek relations. The reforms being implemented today are in contrast to the policy pursued by the former authorities of Uzbekistan.

The policy of "equidistance," as the Uzbek authorities have characterized it [Furstenberg, 2017], appears to be gradually transforming. It is known that Islam Karimov tried to maintain a balance in foreign policy. In the history of independent Uzbekistan there were periods of deference toward the West until 2005, and toward Russia as well. But Uzbek policy never featured an evident rapprochement with China. In this aspect Tashkent always maintained a clear position of limiting Chinese influence and presence in the republic.

Today, there is every reason to believe that the Chinese vector of Uzbekistan's foreign economic activity is intensifying and taking place as primarily desired by Tashkent.

In May 2017, the first visit of Uzbekistan's President Shavkat Mirziyoyev to China took place, following which more than 100 agreements were signed worth a total of $\$ 20$ billion - this is a significant figure given that in 2016 total trade between the Republic of Uzbekistan and the PRC was $\$ 4.2$ billion [Mirziyoyev, 2016]. Moreover, Chinese capital is invested in sectors including oil refining, chemical industry, infrastructure projects and 
the area of hydraulic power engineering. According to Uzbek media, China will assist in the construction of nine new hydroelectric power stations and the upgrade of 15 . This will allow Uzbekistan to produce up to 5.25 billion $\mathrm{kWh}$ of electricity per year.

On the whole, the policy of greater readiness to cooperate with global and regional empires adopted by the new authorities of Uzbekistan had long been in the making and is fully in line with current realities. However, Uzbekistan is required to prevent China's excessive influence and try to maintain a balance.

It is important to understand that China is to some extent trying to reduce the socalled "monopoly" of Kazakhstan as the main and only transit hub and key partner of China in the region. It was with the goal of diluting the influence and role of Kazakhstan in Central Asia that Chinese authorities decided to build the fourth branch of the gas pipeline along a new route, bypassing Kazakhstan.

The initiative was meant to connect Turkmenistan, Uzbekistan, Tajikistan and Kyrgyzstan within one single project. However, this idea turned out to be quite difficult. Thus, the deadline for the project has long since expired, and the construction of sites in Tajikistan, Kyrgyzstan and Uzbekistan is still incomplete. Moreover, in some areas the work has not even begun [Isimov, 2016].

Currently, China is promoting another ambitious project - the China-KyrgyzstanUzbekistan railway. Speaking in Beijing, Sh. Mirziyoyev said that Uzbekistan was interested in building this railway with further connections to the roads of Afghanistan, Turkmenistan and Iran [Wen, 2017]. The authorities of Kyrgyzstan generally support this project.

Thus, there is a general political will among the key participants to support the project. But there are still many unresolved issues, those being the width of the track, the terms of financing and use.

It should be noted that the construction of this railway line is, on the whole, not very profitable for Kazakhstan because it will divert some of the cargo traffic that is currently going through the territory. But on the other hand, the implementation of this project will establish conditions for healthy competition and facilitate improvement of railway border crossings between Kazakhstan and the PRC.

It should also be noted that there is some concern, not only among ordinary citizens but also among the expert community, with respect to the expansion of Chinese influence, in this case in the context of the establishment of 51 enterprises. People in Kazakhstan have observed a continuous expansion of the Chinese presence in the economy since the late-1990s. The increase in the number of Chinese companies operating in Kazakhstan, coupled with the transformation of the PRC into a global economic power and the growth of Beijing's military strength, have generated a cautious attitude.

The goals and objectives of the Silk Road project are to open borders for the free movement of goods and people between China and Central Asia. It is with this that certain risks are most associated, since the prospect of being subsumed within the expansion of China's trade, economic and migration is emerging.

In this context, OBOR is strongly linked to another Chinese project, the free trade area within the SCO. This proposal by Beijing was blocked by Moscow, after which 
Chinese authorities may have changed their tactics, based, first of all, on bilateral cooperation with each of the Central Asian republics. At SCO events, Chinese authorities once again announced their interest in establishing the free trade area within the framework of the SCO [Shtukina, 2015].

Despite official statements by Chinese authorities that the PRC does not aspire to world domination, Beijing appears to be seriously intent on forming an alternative to the existing world order. In financial terms, China has already created multilateral financial structures in the form of the Asian Infrastructure Investment Bank (AIIB) with capital totaling $\$ 800$ billion. At the same time, Beijing has already promoted the idea of free trade area with the Asia-Pacific Economic Cooperation (APEC) countries and established the Silk Road Fund with capital totaling $\$ 40$ billion. The consolidation of the geopolitical aspect of a China-centred world is to be ensured through a long-term strategy focused on both land and sea. The focus on long-term political benefits will determine the secondary nature of China's economic benefits for itself.

Proceeding from the above, during the first stage (presumably lasting from five to seven years), projects within the framework of the OBOR strategy will appear to be extremely beneficial for participants in terms of economic dividends and real profits. In particular, the Chinese projects within this strategy are much more attractive than the Trans-Pacific Partnership (TTP) or Regional Comprehensive Economic Partnership (RCEP). But, in the longer run, these projects will contribute to increasing dependence on Chinese investment and goods on the one hand, and increased distance from western political and economic structures on the other.

At the same time, the Chinese strategy is likely to face serious opposition from the U.S. and its allies, especially in the southeast. Noting the risks of the Chinese strategy, Chinese expert Zhou Wenzhong, secretary general of the Boao Forum for Asia, said that it is necessary to prepare for two challenges: the geopolitical issue and the risk in the field of international finance [Wang, 2015]. In other words, Zhou hints that in the medium term, China will face the same challenges that the United States faced in carrying out its policy in other regions of the world. In particular, sooner or later, an issue will emerge with respect to ensuring stability in those countries in which large investments are made. The OBOR will involve making multibillion dollar investments in countries that are not very stable politically and financially (the countries of Southeast, Central and South Asia, Africa and the Middle East); thus, Chinese authorities need to be ready to use force outside the country and, accordingly, to be criticized by the world community.

Among the potential risks of the Chinese project is a sharp increase in the geopolitical influence of Beijing in the countries of the region. This is due to the fact that in the context of the growing geopolitical confrontation between the U.S. and Russia, especially against the background of western sanctions, they risk missing important moments in Central Asia. Taking advantage of this situation, China is acting to implement the OBOR in the near future.

At the same time, it should be expressly noted that when considering the OBOR, it is customary to take into account external conditions only [Economist Intelligence Unit, 2015]. These conditions include the political and economic situation in Central 
Asia, the readiness of these states to support the projects, the attitude and position of Russia and other centres of power and so on. But, it seems, one should not forget about the internal readiness and, most importantly, the opportunities for the Chinese economy itself to implement such a grandiose project. Today, China has found the necessary finances specifically for the purposes of the Silk Road Economic Belt project, and the OBOR strategy initiated the establishment of two major financial institutions - the Silk Road Fund and the Asian Infrastructure Investment Bank.

It is important to bear in mind that the Chinese economy is entering a dangerous period in its development and it might be at this very moment that China's "economic miracle" could end. According to experts, the Chinese economy will show a high level of public debt by the end of 2017, while the situation in the stock market and the real estate market confirm that the Chinese economy is facing fundamental problems [CAANetwork, 2016].

At the same time, it is necessary to take into account such internal factors as intraparty strife in China. And can ambitious Xi Jinping make any drastic changes to the system of generation-to-generation power transfer at all? All these issues will have a direct impact on the success and stability of OBOR.

\section{OBOR in Interaction with Other Projects in the Region}

Another point intensifies concerns related to the Chinese project. In particular, the role and place assigned by Chinese authorities to Russia in the OBOR strategy is still uncertain. Despite official statements of authorities, as well as plans for a Beijing-Moscow high-speed railway, highway and other projects, China generally assigns an insignificant place to Russia in its strategy. Moreover, by offering road construction projects to Moscow, Beijing apparently expects to divert Russia's attention from its own plans in Central Asia.

China had initially assigned Moscow a special place in the implementation of OBOR. In 2013, Xi stated: "Together with Russia and the countries of Central Asia, we are ready to make joint efforts to build a harmonious region strengthening cooperation and coordination" [Xi, 2013]. Moscow responded by stating its support for the Chinese initiative. Moreover, in May 2015 a joint statement was made specifically to announce the intention to combine the EEU and SREB [President of Russia, 2015].

However, today it appears that the official position of Moscow and especially the Russian expert community has become transformed with respect to the OBOR. In particular, Russia shows interest in the new format while furthering discussions of the prospects for participation in OBOR. Speaking at the forum in Beijing in May 2017, President V. Putin continued promoting the idea of a greater Eurasian partnership, while the idea of combining the EEU and SREB was never mentioned [President of Russia, 2017].

The emphasis placed by the Russian leader shows that Moscow is ready to participate in the Chinese initiative, but within the framework of a more ambitious formula for the Eurasian partnership than within the framework of the combination that had been previously announced. Speaking in Beijing in May 2017, Putin stated: "I think 
that combining the potentials of such integration formats as the EEU, "One Belt, One Road," the Shanghai Cooperation Organisation, the Association of Southeast Asian Nations can form the basis for the establishment of the large Eurasian partnership. It is with this approach that we consider it possible to regard the agenda proposed by the PRC today [President of Russia, 2017].

It is quite clear that the current relationship between Russia and China is characterized by mutual concessions. Each of the parties is interested in the other and in solving its own problems; thus, their competing views are somewhat reduced. But in the long-term geopolitical plan, China and Russia remain rivals, and given the ambitious plans of the PRC to form a China-centred world order, their rivalry is likely to once again become irreconcilable.

However, as recent agreements show, China continues to exercise a combination approach, and China and the EEU announced the completion of negotiations on the Agreement for Trade and Economic Cooperation [Eurasian Economic Commission, 2017].

\section{Conclusion}

The emergence and implementation of the One Belt One Road initiative unequivocally provided a noticeable impetus to cooperation among the countries of Central Asia and China. Many new projects have materialized, including in the real sector of economy and the transport sector.

Since 2013, major changes have taken place as programmes and projects have been implemented under this strategy. In China more than 50 research centres have been established, specializing in Central Asia and Silk Road studies [Belt and Road Database].

Quite a few public and private programmes have emerged in Central Asia riding the wave of the projects implemented within the OBOR framework.

However, the countries of the Central Asian region differ in their vision of and approaches to cooperation with China. It is clear that each country, when developing a strategy of engagement with the PRC, proceeds from its own national interests. Beijing benefits from such disunity by negotiating with each of them separately.

Meanwhile, China itself, as well as its foreign policy and economic activity, is in the process of constant updating or supplementation. In this regard, China's rapid growth and changes in the mechanisms for carrying out foreign economic strategy creates certain risks for its partners.

Being in the same neighbourhood as the PRC, Kazakhstan is one of the first to feel changes in Chinese policy. The process of interaction with China involves a number of real risks. That is why Kazakhstan's foreign policy strategy is based on the principle of multivector activity. That is, while actively participating in the Chinese OBOR initiative, Astana also participates in the processes of Eurasian integration, supports the C5+1 mechanism and closely interacts with European partners as well.

In general, all the countries of Central Asia face the challenge of parity-based cooperation with such a giant as China. China's advantage is obvious in not only the 
scope and scale of its economy, but also in the preparedness of its human resources specializing in the Central Asian region.

At the same time, despite certain contradictions on the part of global and regional powers, the implementation of projects under the auspices of OBOR is in full swing. This is largely due to China's strong financial support.

However, what will happen to the Chinese initiative after China refuses to finance all projects in a row? In fact, we are already observing this. Indeed, despite the need for an image component of OBOR, the Chinese economy cannot afford to finance all existing projects.

Moreover, recent studies show that large infrastructure projects financed by China within the framework of OBOR share a major drawback in the low efficiency of subsequent management [Golunov, 2017; Shepard, 2017]. This leads to a cost overrun. At the same time, western experts point to the growing political influence of China in those countries where it finances projects and programmes [Pop, 2016]. With that in mind, OBOR leads to an increased dependence on China, which is in no one's interest.

In general, there are many questions on the subsequent fate of OBOR from the Central Asian perspective still to be answered. And in this context, many things will depend on a combination of factors that include the position and policies of the Central Asian countries themselves, further vision and approaches practiced by China, the position and actions of Russia as a key player in the region and the activity of other centres of power as well.

\section{References}

Akchabar Print (2017) China and Kyrgyzstan Discuss the Creation of a Development Fund. 20 July. Available at: https://www.akchabar.kg/news/kitaj-i-kyrgyzstan-obsuzhdayut-sozdanie-fonda-razvitiya/ (accessed 27 July 2018) (in Russian).

Asia-Plus (2017) China Outweighs Russia on Direct Investments in Tajikistan. 2 February. Available at: https://news.tj/ru/news/tajikistan/economic/20170202/kitai-oboshel-rossiyu-po-pryamim-investitsiyam-v-tadzhikistan (accessed 27 July 2018) (in Russian).

Atambayev A. (2017) Kyrgyzstan Expresses Readiness to Pair the Concept of "One Belt, One Road" with "Taza Koom." 15 May. Available at: http://kabar.kg/news/kyrgyzstan-vyrazhaet-gotovnost-k-sopriazheniiu-kontceptcii-odin-poias-odin-put-s-taza-koom-a.atambaev/ (accessed 27 July 2018) (in Russian).

Belt and Road Database (n.d.) Available at: http://www.ydylcn.com/ (accessed 27 July 2018) (in Chinese).

Bondarenko K. (2016) Tajikistan's External Debt: Growing Risks Against the Background of Fragile Stability. 12 October. Available at: http://cabar.asia/ru/konstantin-bondarenko-vneshnij-dolg-tadzhikistanarastushhie-riski-na-fone-hrupkoj-stabilnosti/ (accessed 27 July 2018) (in Russian).

CAA Network (2016) Sarah Lane: Chinese Investment in Central Asia will Continue Despite Slowdown in Economic Growth. 5 June. Available at: http://caa-network.org/archives/7200 (accessed 27 July 2018) (in Russian).

Economist Intelligence Unit (2015) Prospects and Challenges on China's “One Belt, One Road:” A Risk Assessment Report. Available at: https://iffo.org.hk/docs/default-source/Default/ge-one-belt-one-roadreport-engversion_economistc63aa06efc2665b498f6ff0000d93771.pdf (accessed 27 July 2018)

Eurasian Economic Commission (2017) China and the EEU Announced the Completion of Negotiations on the Agreement for Trade and Economic Cooperation. 10 February. Available at: http://www.eurasiancommission.org/en/nae/news/Pages/2-10-2017-5.aspx (accessed 27 July 2018). 
Furstenberg S. (2017) Uzbekistan: Mirziyoyev Seeks Changes, but Will He Manage? 3 October. Available at: http://russian.eurasianet.org/node/64796 (accessed 27 July 2018) (in Russian).

Golunov S. (2017) Russian and Chinese Influences in Shared Borderlands. January. Available at: http:// www.ponarseurasia.org/memo/russian-and-chinese-influences-shared-borderlands (accessed 27 July 2018).

Gezitter (2017) The Creation of the Kyrgyz-Chinese Business Development Fund. 7 July. Available at: http://www.gezitter.org/politic/61380/ (accessed 27 July 2018) (in Russian).

Isimov R. (2016) China and Turkmenistan: A Regional Dimension. 17 August. Available at: http://cabar. asia/ru/ruslan-izimov-kitaj-i-turkmenistan-regionalnoe-izmerenie/ (accessed 27 July 2018) (in Russian).

K-News (2016) Foreign Debt of Kyrgyzstan: The Amount and What Has Changed (Schedule). 6 September. Available at: http://knews.kg/2016/09/foreign-debt-1992-2016/ (accessed 27 July 2018) (in Russian).

Khassanova S. (2017) During the Independence of Central Asia, China Has Become Its Main Economic Partner. 22 September. Available at: http://caa-network.org/archives/10334 (accessed 27 July 2018) (in Russian).

Lee T. (2014) China and Kazakhstan Build the Silk Road Economic Belt. 16 October. Available at: http:// finance.eastmoney.com/news/1350,20141016434649817.html (accessed 27 July 2018) (in Chinese).

Mirziyoyev (2016) The Trade Turnover between Uzbekistan and the PRC in 2017 Will Amount to \$5 Billion. 13 May. Available at: http://regnum.ru/news/2274429.html (accessed 27 July 2018) (in Russian).

Pop I.I. (2016) Strengths and Challenges of China's "One Belt, One Road" Initiative. Centre for Geopolitics \& Security in Realism Studies, 9 February. Available at: http://www.cgsrs.org/files/files/publications_46.pdf (accessed 27 July 2018).

President of Russia (2015) Joint Statement of the Russian Federation and the People's Republic of China on Cooperation in Combining the Construction of the Eurasian Economic Union and the Silk Road Economic Belt. 21 July. Available at: http://kremlin.ru/supplement/4971 (accessed 27 July 2018).

President of Russia (2017) "One Belt, One Road” International Forum. 14 May. Available at: http://kremlin.ru/events/president/news/54491(accessed 27 July 2018) (in Russian).

Shepard W. (2017) China's Challenges Abroad: Why The Belt \& Road Initiative Will Succeed. 17 October. Available at: https://www.forbes.com/sites/wadeshepard/2017/10/17/chinas-challenges-abroad-5-reasons-why-the-belt-road-will-succeed/\#ce78a994a826 (accessed 27 July 2018).

Shtukina E. (2015) China Proposes to Establish a Free Trade Area Within the SCO. 15 December. Available at: http://tass.ru/ekonomika/2527761 (accessed 27 July 2018) (in Russian).

Syroyezhkin K. (2016) Geopolitical Projects in Central Asia and the Role of Kazakhstan. 30 March. Available at: http://cabar.asia/ru/konstantin-syroezhkin-geopoliticheskie-proekty-v-tsentralnoj-azii-i-rol-kazahstana/ (accessed 27 July 2018) (in Russian).

Wang G. (2015) Zhou Wenzhong Secretary-General of the Boao Forum: First We Need to Develop a Project Template for the "Belt and Road" Construction. 23 March. Available at: http://finance.people.com. cn/n/2015/0323/c394778-26735349.html (accessed 27 July 2018) (in Chinese).

Wen X. (2017) President of Uzbekistan: It Is Necessary to Promote Further Deepening of Friendly Chinese-Uzbek Relations. 10 May. Available at: http://oversea.huanqiu.com/article/2017-05/10635499.html (accessed 27 July 2018) (in Chinese).

Xi J. (2013) Speech by President Xi Jinping of the People's Republic of China at the Nazarbayev University (full text) 16.09.2013 // Available at: http://kz.china-embassy.org/rus/zhgx/t1077192.htm (accessed 27 July 2018).

Xi J. (2014) The Governance of China. Beijing: Foreign Languages Press. P. 385-395.

Xi J. (2017) Speech at the International Forum "Belt and Road" Opening Ceremony. 14 May. Available at: http://news.xinhuanet.com/politics/2017-05/14/c_1120969677.htm (accessed 27 July 2018) (in Chinese).

Zakon (2016) The Programme of Transferring Industrial Facilities from the PRC to the RK Includes 51 Projects Worth \$26 Billion. 2 September. Available at: http://www.zakon.kz/4814888-programma-perenosa-moshhnostejj-knr-v.html (accessed 27 July 2018) (in Russian). 


\title{
Центральноазиатский трек инициативы «Пояс и путь»: возможности и риски ${ }^{1}$
}

\author{
Р.Ю. Изимов, З.Т. Мураталиева
}

Изимов Руслан Юсупжанович - руководитель Программы евразийских исследований Института мировой экономики и политики при Фонде Первого Президента РК - Елбасы; Республика Казахстан, 010000, Астана, ул. Бокейхана, д. 10; E-mail: iziruslan@mail.ru

Мураталиева Замира Тулкуновна - к.полит.н., доцент, ученый секретарь Института стратегического анализа и прогноза Кыргызско-Российско-Славянского университета; Кыргызская Республика, 720000, Бишкек, просп. Чуй 42; E-mail: nargi84@yandex.com

Более четверти века, с момента обретения независимости, большинство стран Центральной Азии, за исключением Туркменистана, последовательно реализуют главный принцип внешней политики - многовекторность. За прошедший период данная стратегия показала свою эффективность и незаменимость.

Стремясь удерживать хрупкий баланс между интересами глобальных и региональных держав, Казахстан и другие страны региона и сегодня продолжают политику многовекторности. Однако нужно признать, что данная задача с каждым годом усложняется ввиду ужесточения конкуренции между региональными акторами. В этом плане особую роль играет появление и реализация китайской инициативы «Пояс и путь», которая объективно увеличивает зависимость стран региона от Китая.

В статье анализируется процесс появления и реализации китайской инициативы «Пояс и путь» в Центральной Азии. Авторы подробно описывают внешнеполитическую стратегию Пекина с появлением инициативы ОПОП с точки зрения ее основных компонентов в Центральной Азии.

Отдельно рассматривается сотрудничество Казахстана и Китая в рамках идеи стыковки Государственной программы инфраструктурного развития «Нұрлы жол» на 2015-2019 г2. и ОПОП. С учетом долгосрочности указанного проекта даются прогнозы взаимодействия государств Центральной Азии с Поднебесной в рамках китайской инициативы.

Также затрагиваются вопросы дальнейшего сосуществования нескольких проектов на евразийском пространстве, в которых участвуют Казахстан и другие страны региона. В частности, авторы анализирует роль и место, отведенное китайскими властями России в стратегии ОПОП. Несмотря на официальные заявления властей, а также намечаемые планы, по большому счету Китай отводит России несущественное место в своей стратегии. Более того, предложив Москве указанные проекты строительства дорог, Пекин, судя по всему, рассчитывает отвлечь внимание России от собственных планов в Центральной Азии. На этом фоне наблюдается определенная ответная реакция Москвы, что наиболее ярко проявляется в стремлении России вновь продвигать проект «Большого евразийского партнерства».

Ключевые слова: китайская инициатива «Пояс и путь»; ОПОП; «Нурлы жол»; Казахстан; центральноазиатская стратегия; страны Центральной Азии; геополитика

Для цитирования: Изимов Р.Ю., Мураталиева 3.Т. (2018) Центральноазиатский трек инициативы «Пояс и путь»: возможности и риски // Вестник международных организаций. Т. 13. № 3. С. 128-142 (на русском и английском языках). DOI: 10.17323/1996-7845-2018-03-08.

\section{Источники}

Атамбаев А. (2017) Кыргызстан выражает готовность к сопряжению концепции «Дин пояс - один путь» с «Таза коом». 15 мая. Режим дотупа: http://kabar.kg/news/kyrgyzstan-vyrazhaet-gotovnostksopriazheniiu-kontceptcii-odin-poias-odin-put-s-taza-koom-a.atambaev/ (дата обращения: 25.07.2018).

${ }^{1}$ Статья поступила в редакцию в ноябре 2017 г. 
Бондаренко К. (2016) Внешний долг Таджикистана: растущие риски на фоне хрупкой стабильности. 12 октября. Режим доступа: http://cabar.asia/ru/konstantin-bondarenko-vneshnij-dolgtadzhikistanarastushhie-riski-na-fone-hrupkoj-stabilnosti/ (дата обращения: 26.07.2018).

Ван Г. (2015) Boao yazhou luntan mishu zhang zhouweozhong: Yidai yilu jianshe shouxian ying nachu xiangmu moban [Генеральный секретарь Форума Боао Чжоу Вэньчжун: для строительства «Пояса и пути» сначала нужно разработать шаблон проекта]. 23 марта. Режим доступа: http://finance.people. com.cn/n/2015/0323/c394778-26735349.html (дата обращения: 27.07.2018) (на кит. яз.)

Вэнь С. (2017) Wuzibiekesitanzongtong: tuidong zhongwu youhao hezuo geng shangceng lou [Президент Узбекистана: необходимо содействовать дальнейшему углублению дружественных китайско-узбекских отношений]. 10 мая. Режим доступа: http://oversea.huanqiu.com/article/2017-05/10635499.html (дата обращения: 27.07.2018) (на кит. яз.)

Евразийская экономическая комиссия (ЕЭК) (2017) Китай и ЕАЭС объявили о завершении переговоров по Соглашению о торгово-экономическом сотрудничестве. 2 октября. Режим доступа: http://www. eurasiancommission.org/ru/nae/news/Pages/2-10-2017-5.aspx (дата обращения: 27.07.2018).

ИА Азия-плюс (2017) Китай обошел Россию по прямым инвестициям в Таджикистан. Режим доступа: https://news.tj/ru/news/tajikistan/economic/20170202/kitai-oboshel-rossiyu-po-pryamim-investitsiyamvtadzhikistan (дата обращения: 26.07.2018).

Изимов Р. (2016) Китай и Туркменистан: региональное измерение. Центральноазиатское бюро аналитической журналистики. 17 августа. Режим доступа: http://cabar.asia/ru/ruslan-izimov-kitajiturkmenistan-regionalnoe-izmerenie (дата обращения: 26.07.2018).

Ли Т. (2014) Китай и Казахстан строят Экономический пояс Шелкового пути. 16 октября. Режим доступа: http://finance.eastmoney.com/news/1350,20141016434649817.html (дата обращения: 25.07.2018) (на кит. яз.).

Мирзиеев Ш. (2016) Товарооборот между Узбекистаном и КНР в 2017 г. составит \$5 млрд. 13 мая. Режим доступа: regnum.ru/news/2274429.html (дата обращения: 25.07.2018).

Президент России (2015) Совместное заявление Российской Федерации и Китайской Народной Республики о сотрудничестве по сопряжению строительства Евразийского экономического союза и Экономического пояса Шелкового пути. 8 мая. Режим доступа: http://kremlin.ru/supplement/4971 (дата обращения: 26.07.2018).

Президент России (2017) Международный форум «Один пояс, один путь». 14 мая. Режим доступа: http://kremlin.ru/events/president/news/54491 (дата обращения: 26.07.2018).

Си Цзиньпин (2013) Укреплять дружбу народов, вместе открыть светлое будущее. Выступление Председателя КНР Си Цзиньпина в Назарбаев университете (полный текст). 16 сентября. Режим доступа: http://kz.china-embassy.org/rus/zhgx/t1077192.htm (дата обращения: 25.07.2018).

Си Цзиньпин (2014) Си Цзиньпин о государственном управлении. С. 385-395.

Си Цзиньпин (2017) Xi Jinping zai "Yi dai yi lu” guoji hezuo gaofei luntai kaimushi shangde yanjiang [Речь Си Цзиньпина на церемонии открытия Международного форума «Пояс и путь»]. 14 мая. Режим доступа: http://news.xinhuanet.com/politics/2017-05/14/c_1120969677.htm (дата обращения: 25.07.2018) (на кит. яз.).

Сыроежкин Г. (2016) Геополитические проекты в Центральной Азии и роль Казахстана. 30 марта. Режим доступа: http://cabar.asia/ru/konstantin-syroezhkin-geopoliticheskie-proekty-v-tsentralnoj-azii-irolkazahstana/ (дата обращения: 25.07.2018).

Хасанова С. (2017) За время независимости Центральной Азии Китай превратился в ее главного экономического партнера. 22 сентября. Режим доступа: http://caa-network.org/archives/10334 (дата обращения: 25.07.2018).

Штукина Е. (2015) Китай предлагает создать зону свободной торговли в рамках ШОС. ТАСС. 15 декабря. Режим доступа: http://tass.ru/ekonomika/2527761 (дата обращения: 26.07.2018).

Фурстенберг С. (2017) Узбекистан: Мирзиеев хочет перемен, но справится ли он? 4 октября. Режим доступа: http://russian.eurasianet.org/node/64796 (дата обращения: 26.07.2018). 
Akchabar Print (2017) Китай и Кыргызстан обсуждают создание фонда развития. 20 июля. Режим доступа: https://www.akchabar.kg/news/kitaj-i-kyrgyzstan-obsuzhdayut-sozdanie-fonda-razvitiya/ (дата обращения: 25.07.2018).

Belt and Road Database (с. а.) Режим доступа: http://www.ydylcn.com/ (дата обращения: 26.07.2018) (на кит. яз.).

Economist Intelligence Unit (2015) Prospects and Challenges on China's "One Belt, One Road:” A Risk Assessment Report. Режим доступа: https://iffo.org.hk/docs/default-source/Default/ge-one-belt-oneroadreport-engversion_economistc63aa06efc2665b498f6ff0000d93771.pdf (дата обращения: 25.07.2018).

Gezitter (2017) Рассматривается создание кыргызско-китайского фонда развития бизнеса. 7 июля. Режим доступа: http://www.gezitter.org/politic/61380/ (дата обращения: 25.07.2018).

Golunov S. (2017) Russian and Chinese Influences in Shared Borderlands. Январь. Режим доступа: httр:// www.ponarseurasia.org/memo/russian-and-chinese-influences-shared-borderlands (дата обращения: 26.07.2018).

K-News (2016) Внешний долг Кыргызстана: сколько должны и что изменилось. 6 сентября. Режим доступа: http://knews.kg/2016/09/foreign-debt-1992-2016/ (дата обращения: 25.07.2018).

Lain S. (2017) Sarah Lain on the Chinese Investment in Central Asia // CAA-Network, 5 июня. Режим доступа: http://caa-network.org/archives/7200 (дата обращения: 26.07.2018).

Pop I.I. (2016) Strengths and Challenges of China's “One Belt, One Road” Initiative. Centre for Geopolitics \& Security in Realism Studies, 9 февраля. Режим доступа: http://www.cgsrs.org/files/files/publications_46. pdf (дата обращения: 26.07.2018).

Shepard W. (2017) China’s Challenges Abroad: Why The Belt \& Road Initiative Will Succeed. 17 октября. Режим доступа: https://www.forbes.com/sites/wadeshepard/2017/10/17/chinas-challenges-abroad-5-reasonswhy-the-belt-road-will-succeed/\#ce78a994a826 (дата обращения: 26.07.2018).

Zakon (2016) Программа переноса мощностей КНР в РК включает 51 проект на \$26 млрд. 2 сентября. Режим доступа: http://www.zakon.kz/4814888-programma-perenosa-moshhnostejj-knr-v.html (дата обращения: 25.07.2018). 